\title{
The New Botanical Building at the University of Toronto
}

TTHE University of Toronto owes much to the able 1 and wise administration of the retiring president, Sir Robert Falconer: by the part he played in securing adequate provision for teaching and research

Robert Falconer; his successor, the Rev. Dr. Cody, chairman of the Board of Governors, and others, walked in procession to the new building, which was opened by the Prime Minister.

The Prime Minister paid a tribute to the architects,

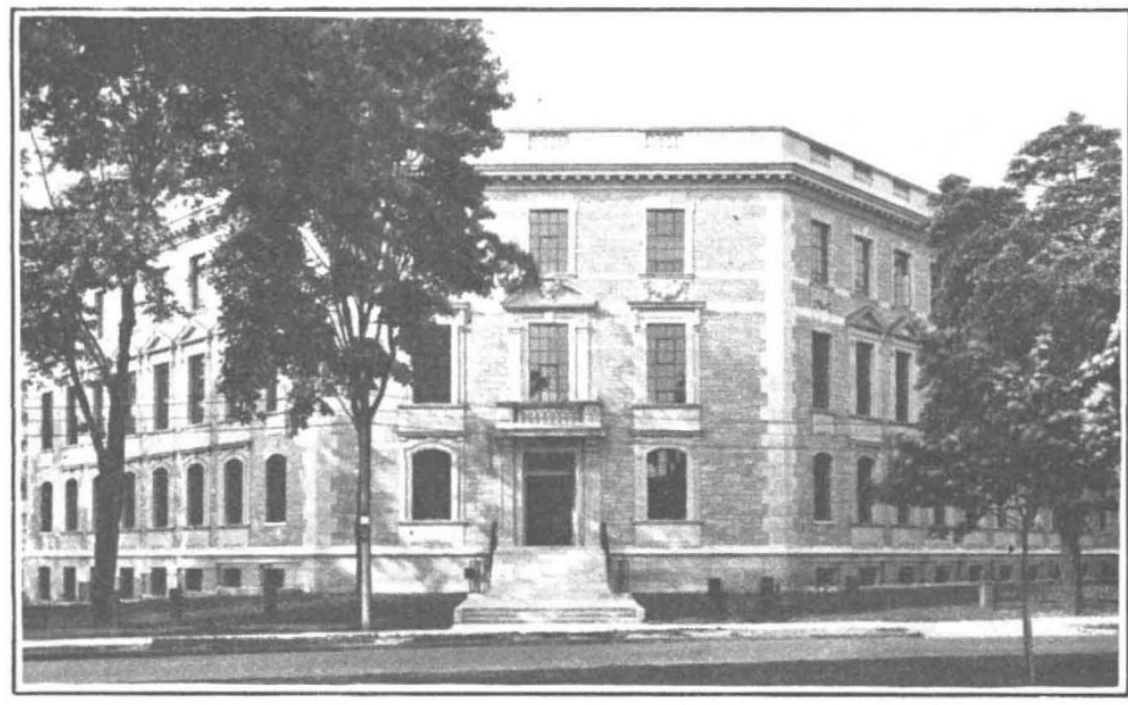

FrG. 1.-Front view, showing the main entrance of the new botanical buildings of the University of Toronto.

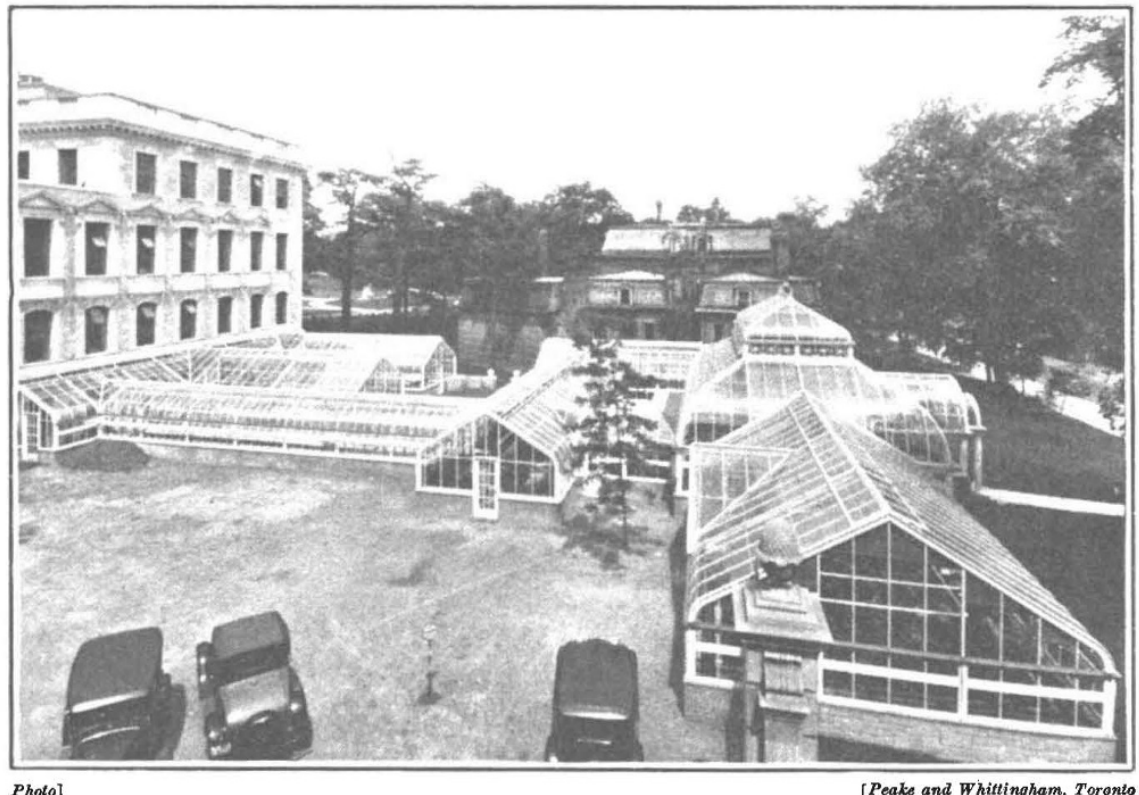

hoto

[Peake and Whittingham, Toronts

FIG. 2.-The range of glass-houses behind a wing of the new botanical building, University of Toronto. Messrs. Mathers and Haldenby, both of whom are graduates of the University, and stated that all the material used in construction was Canadian. In handing over thè building to the chairman of the Governors, he said that it should be regarded as an expression of the interest of the Government. the legislature, and the people of the province in the cause of higher education.

Dr. Cody, in accepting the building, spoke of botany as one of the first subjects taught in the early days, in 1843, when the University was known as King's College. Botany was then one of several sciences for which the professor of experimental philosophy was responsible. In 1853, when King's College was promoted to university status, the Rev. William Hincks was appointed professor of natural history: one of the applicants for the chair was Thomas Henry Huxley. The present head of the department, Prof. R. B. Thomson, was appointed to that position in 1928.

Dr. Cody gave a brief account of the building, which he described as one of the most attractive in the University group. It was erected at an inclusive cost of 517,000 dollars on a site at the entrance to Queen's Park : there is a well-lighted ground-floor with three floors above arranged round a central court. The inside walls are lined with bare brick : there is about an acre of floor space. On the ground-

in botany he has earned the gratitude of all who are interested in that branch of biology. One of his last acts in Commencement Week of this year was to assist at the formal opening of the new Botanical Department on June 8. After an informal luncheon given to the visiting botanists, the Chancellor of the University, Sir William Mulock; the Prime Minister of Ontario, Mr. G. S. Henry; the President, Sir floor and the floor above, provision is made for plant pathology and plant physiology under Dr. D. L. Bailey and Dr. G. H. Duff; on the second floor are laboratories for morphology and the anatomy of flowering plants under the personal charge of Prof. Thomson : mycology under Prof. H. S. Jackson, seed laboratories under Dr. H. B. Sifton, and the herbarium are on the third floor. Ample provision is made for 
research rooms. Adjoining the building is a range of glass-houses. Dr. Cody added that about a thousand undergraduates would be accommodated in the new laboratories.

Sir Robert Falconer invited five of the botanical delegates to give short addresses : Prof. A. C. Seward of the University of Cambridge; Prof. K. M. Wiegand of Cornell University; Dr. H. T. Güssow, the Dominion botanist; Prof. Marie-Victorin of the University of Montreal; and Prof. F. E. Lloyd of McGill University. On the following day the honorary degree of Sc.D. was conferred upon Prof. A. C. Seward.

\section{Plant Products of the British Empire}

HROM prehistoric times, man has depended to a considerable extent upon plant products, from various economic points of view. Some such products are necessities and others are luxuries. Some which were primarily luxuries have now become, with the great changes in human civilisation and habit, quite essential to human needs. These constant changes and new developments in human needs as regards the vegetable kingdom formed the basis of Sir Arthur Hill's evening discourse delivered at the York meeting of the British Association on Sept. 2, entitled "Plant Products of the Empire in Relation to Human Needs".

The economic botanist seeks to satisfy our human needs, both natural and artificial, and with the tremendous modern developments in human life and habit, his work has become of primary importance. With such a widely scattered Empire, Great Britain is able to supply itself very largely from its own colonies and dominions. Two great 'cravings' of to-day-newspapers and motor cars-are resulting in the destruction of the magnificent forests of Canada and Newfoundland and the extensive plantations of Hevea brasiliensis, the latex of which supplies the raw rubber, in various parts of the Empire.

Fortunately for Great Britain, it is possible, to a great extent within the Empire, to meet the growing demand for various plant products, such as oils and fats, cereals, fruit, animal foods, spices and condiments, beverages, gums and resins, drugs, tobacco, clothing, timber, etc. Certain other industries are fast disappearing, owing to changes in present-day methods and fashions. For example, indigo, camphor, and vanilla are giving place to synthetic substitutes, and cotton and flax have a strong competition in artificial silk. Another group of the Empire's plant resources, often lost sight of, because it does not appear on the world's markets, is native products used chiefly by those who cultivate them. The importance of such
Empire products is scarcely ever realised until such times as famine and crop failure.

During the course of his address, Sir Arthur indicated the original homes, throughout the British Empire, of some of the economic plants. Efforts are still being made to find plants of economic value which can be grown within the Empire, with the ultimate aim of making the Empire self-supporting so far as possible. With the large increase in cultivated areas, complications such as plant diseases have been set up, necessitating the creation of an army of specialistsplant pathologists, entomologists, physiologists, etc. Rust on wheat in Canada, for example, is estimated to destroy annually $£ 5,000,000$ worth of wheat. Every year, in the British Empire alone, insects destroy enough food to supply forty-five million people.

The band of scientific workers attached to the various departments of plant economic and agricultural research throughout the Dominions and Colonies seems a rather formidable one, yet their numbers and cost of maintenance are negligible compared with the toll levied by the diseases they are attempting to overcome.

Since its inception, the Empire Marketing Board has given invaluable help in the war against plant diseases, in research on plant storage, etc., and it has spent $£ 1,235,000$ in grants for research. In many cases, too, research is supported financially by firms which depend upon the various plant products for their raw materials. For example, Messrs. Rowntree, Cadbury, and Fry are supporting the research work on cacao now being carried out at Trinidad.

The scientific problems confronting the Empire in connexion with our supplies of plant products offer a fitting outlet both for private and public munificence, and those who come forward to support the new culture of scientific research and its application to human needs will realise that they are not merely satisfying a noble enthusiasm, but are also fulfilling one of the pressing needs of the Empire.

\section{Electricity Supply in New York}

$\mathrm{N}^{\mathrm{o}}$ city in the world owes more to the advance of engineering than New York, within the boundaries of which are to be found some of the finest bridges, tunnels, subways, high buildings, and power stations ever constructed. The progress of these great undertakings is dealt with from time to time in our own technical journals, and in Engineering for May 13, 27, and June 17 is given a well-illustrated account of the present position of the electrical supply schemes in the city.

Fifty years have elapsed since Edison erected the first public electric supply station in Pearl Street, and that was but the beginning of the great interconnected stations by which New York and the suburbs are served to-day. The greater part of New York is now served by the Consolidated Gas Company, which in 1928 obtained control of five separate undertakings serving an area of 550 square miles and a population of $6,017,702$. In 1927 , the last complete year that the five companies operated as separate concerns, the total output was $4,000,000,000$ kwh. and the plant installed had a total capacity of $1,400,000 \mathrm{kw}$. The capacity of the plant by September 1930 had been increased to $2,009,700 \mathrm{kw}$., and plans are now in hand for a further increase in plant designed to meet a demand which it is estimated will by 1940 be three times as great as that in 1927 .

At present, power is generated in seven stations, of which Hell Gate Station has plant of $605,000 \mathrm{kw}$. and Hudson Avenue Station plant of $560,000 \mathrm{kw}$. At Pearl Street Station direct current was generated and distributed, but to-day all current is generated by alternators, the frequency being either 25 cycles or 60 cycles, frequency changers being installed so that current is available from any station for any part of the system. Interconnexion is to be carried still further by the erection of a transmission line to Schenectady, thus enabling power to be brought to New York from Niagara.

A new problem in the economical distribution of electricity arose with the erection in New York of very high buildings, and in Engiveering for June 17

No. 3280, VoL. 130] 